\title{
Analysis of Thyroid Hormone-Dependent Genes in the Brain by In Situ Hybridization
}

\author{
Juan Bernal and Ana Guadaño-Ferraz
}

\section{Introduction}

\subsection{Thyroid Hormone and Brain Development}

Among the most dramatic actions of thyroid hormone are those exerted on brain development and function. In the adult human brain, a deficiency or excess of thyroid hormone may lead to various psychiatric manifestations, but it is during development when thyroid hormone exertsitsmost taried and critical actions on neural tissue. In humans, a deficiency ofthyrbid hormone taking place during a critical period of development may lead to severe mental retardation and also to neurorogical defects (1). This critical period ma $\overline{\text { extend }}$ from the start of the second trimester of pregnancy to the first fem months after birth. During this period, the absence of thyroid hermone, if not courected by early postnatartreatment, eads to inreversible damage with mental retardation. While in utero, the fetal brain is protected from thyroid deficiency by the maternal hormene. Severe thyroid hormone deficiency in the pregnant woman, especially if combined with fetal deficiency, leads to severe neurological deficits in the child that are irreversible even with early postnatal treatment.

In the most studied model of thyroid hormone deficiency, the severely hypothyroid rat, there are no gross alterations of brain morphology. However, there are defects of myelination, alterations of cell migration in the cerebral cortex and the cerebellum, and abnormal differentiation of many neurons, including cholinergic cells and cerebellar Purkinje cells, with severe functional consequences (2).

Elucidation of the molecular basis of thyroid hormone action in the brain is important because it may help to understand how epigenetic factors modify the

From: Methods in Molecular Biology, Vol. 202: Thyroid Hormone Receptors: Methods and Protocols Edited by: A. Baniahmad (๑) Humana Press Inc., Totowa, NJ 


\section{Uncorrected Proof Copy}

basic layout of the central nervous system (CNS) and is a necessary requisite for possible therapeutic interventions. Specific nuclear T3 binding can be detected in the rodent brain from about embryonic d 14 (E14) (3) and the receptor mRNAs from as early as E11.5 (4). In the human fetus, the receptor is present from at least the onset of the second trimester (5). The role of thyroid hormone in brain development appears to be the fine tuning of gene expression, and several genes have been found to be either up-regulated or downregulated during particular time windows. In the rat, this sensitive period extends from prenatal d 18 to postnatal d 25-30. In this chapter, we will provide a short summary of the genes that have been identified so far as dependent of the thyroidal status. In some of these genes, thyroid hormone responsive elements (TRE) have been found, indicating that they probably are direct targets of T3 (for instance, MBP, RC3, PCP2, and prostaglandin D2 synthase). In others, no TRE have yet been identified, although in some instances the regulation of gene expression by $\mathrm{T} 3$ in cultured cells, in addition to in vivo in the whole animal, also suggests a direct action of the hormone. It is likely that many of the thyroid hormone-dependent genes are regulated indirectly, as a consequence of a distant primary action of T3. Detailed examination of gene expression by thyroid hormone in the brain is out of the scope of the present chapter. What follows is a brief description of -some of the gene categories found to be under thy roid hormone regulation (for a review, see ref. 6).

\subsection{Genes of Myelination}

Myelination in the CNS is capried out by oligedendroeytes, a special type of glial cells whoseterminal differentiation is greatly influenced by thyroid hormone (7). Accordingly all the genes encoding proteins of myelin (8), such as myelin basic protein (MBP), myelin-associated glycoprotein (MAG), proteolipid protein (PLP), and cyclic nucleotide phosphohydrolase (CNP) are under thyroid hormone control in vivo with a similar timing. Dependency of these genes from thyroid hormone is transient, so that in the hypothyroid neonatal rat there is a delayed accumulation of mRNA and protein, but eventually they reach normal levels even in the absence of thyroid hormone treatment and become thyroid hormone independent.

\subsection{Mitochondrial Genes}

Thyroid hormone affects mitochondrial gene expression in vivo and in vitro. In brain mitochondria several nuclear-encoded (cytochrome c oxidase subunits IV and VIc (9), and a mitochondrial protein import receptor, homologue to the fungal Tom70 (10) and mitochondrial-encoded (subunit 3 of NADH dehydrogenase (11), subunit III of cytochrome c oxidase, and 12S and 16S rRNAs (9) mRNAs have been observed to be down-regulated in hypothyroidism.

\section{Uncorrected Proof Copy}




\section{Uncorrected Proof Copy}

Thyroid Hormone-Dependent Genes in The Brain

\subsection{Neurotrophins and their Receptors}

NGF, trkA, and $\mathrm{p} 75^{\mathrm{NTR}}$ mRNAs are decreased in hypothyroid rats and increased after thyroid hormone treatment (12). These genes are responsive both in neonatal and in adult rats. Other neurotrophins, such as NT-3 are also under thyroid hormone regulation in specific cells of the cerebellum (13).

\subsection{Cytoskeletal Components}

Thyroid hormone differentially affects the expression of tubulin isoforms. For example, T $\alpha 1$ tubulin is down-regulated by thyroid hormone, whereas the $\beta 4$ isoform is up-regulated (14). Microtubule-associated proteins are also affected by hypothyroidism and thyroid hormone treatment. Tau splicing is regulated by thyroid hormone, which promotes the transition from the juvenile to the mature form (15), and the accumulation of MAP-2 protein is delayed in the hypothyroid animal.

\subsection{Transcription Factors and Splicing Regulators}

Some transcription factors have been found to be under thyroid hormone influence in vivo, including the early response gene $N G F(A$ (A6), the orphan receptor ROR $\alpha(17)$, and basic transcription element-binding protein (BTEB) (18). The regulation of transcription factors expression by thyroid hormone obviously should have farreaching physiological consequences. However, it is unknown how the regulated transcription factor target genes are modified in response to thyroid hormone deficiency or excess. In addition to regulation of transcription, recent data suggest that thyroid hormone could be involved insplicing meehanisms by modifying the expression of splicing regulators (19)

\subsection{Extracellular Matrix Proteins}

Extracellular matrix proteins such as tenascin-C, laminin and reelin, and cell adhesion molecules, such as NCAM and L1 are also regulated by thyroid hormone during the late prenatal and immediate postnatal period in the rat (20-22). Tenascin-C, NCAM, and L1 are down-regulated by the hormone, whereas laminin and reelin are up-regulated. The control of these proteins, especially reelin, is important for proper neuronal migration in the cerebral cortex, cerebellum, and other brain areas.

\subsection{Genes Encoding Proteins Involved in Intracellular Signaling}

The expression of a number of proteins involved in cell signaling in different parts of the CNS are under thyroid hormone control. These include RC3/ neurogranin, a protein kinase $\mathrm{C}$ substrate and calmodulin-binding peptide (23),

\section{Uncorrected Proof Copy}




\section{Uncorrected Proof Copy}

calmodulin-dependent kinase IV (24), prostaglandin D2 syntase (25), and Rhes, a novel Ras protein homolog preferentially expressed in the striatum (26).

\subsection{Methodology Used to Study the Influence of Thyroid Hormone on Regional Brain Gene Eexpression}

The study of gene expression in the CNS requires techniques that allow regional and cellular resolution. To examine the regional and cellular distribution of specific mRNAs, in situ hybridization should be used. This technique is based on the hybridization of a labeled probe to the mRNA present in the tissue. The probe can be either DNA or RNA. DNA probes can be prepared from cDNA or from oligonucleotides. The highest specificity and signal-to-noise ratios are achieved with RNA probes, or riboprobes. These are complementary RNAs synthesized in vitro with phage RNA polymerases using as template the specific cDNA. Depending on the position of the polymerase promoter relative to the cDNA sequence, sense or antisense riboprobes can be synthesized. The antisense RNA will hybridize to tissue mRNA, whereas the sense RNA will not and is used as a control of the hybridization. There are a number of techniques to label the probes using either isotopic or nonisotopic methods (for descriptions of different methods and apptications, see refs. 27-29). Among the nonisotopic, digoxygenin of biotinylated probes are the most commonly used mour experience, the use of radioactive probes, in general, provides more sensitivity and specificity than nonisotopic probes, gith latter allows the visualization of cell horphology. Radioactive probes also allow for quantification of the signat. If a nonisotopic method is used for simplicity, convenience, on to avold nadioactive waste, it is advisable to compare the hybridization pattern with that obtained using an isotopic probe.

In this chapter, we describe an isotopic in situ hybridization method which is currently used in our laboratory. Sections from the rat brain are hybridized in flotation with $\left[{ }^{35} \mathrm{~S}\right] \mathrm{UTP}$-labeled riboprobes. The use of floating sections results in better signal-to-noise ratios than hybridizing the sections previously immobilized on glass slides, although the analysis of fragile and/or small sections, for example those obtained from embryonic tissue, is more difficult. After hybridization, the signal can be detected by autoradiography, using X-ray films, or photographic emulsions. Autoradiography using X-ray films provides a regional pattern of expression of the target. Emulsion autoradiography is used when cellular resolution is desired. If combined with immunohistochemistry, the cells expressing the gene of interest can be identified using specific antibodies.

\section{Uncorrected Proof Copy}




\section{Uncorrected Proof Copy}

Thyroid Hormone-Dependent Genes in The Brain

\section{Materials}

\subsection{Materials Needed for Handling the Animals}

1. $1 M$ phosphate buffer (PB), $\mathrm{pH} 7.2-7.4$ : Mix $610 \mathrm{~mL}$ of $1 M \mathrm{Na}_{2} \mathrm{HPO}_{4}$ and $390 \mathrm{~mL}$ of $1 M \mathrm{NaH}_{2} \mathrm{PO}_{4}$ to final volume of $1 \mathrm{~L}$.

2. Phosphate-buffered saline (PBS): for $1 \mathrm{~L}$ of a $10 \mathrm{X}$ stock solution dissolve $80 \mathrm{~g}$ $\mathrm{NaCl}, 2 \mathrm{~g} \mathrm{KCl}, 2 \mathrm{~g} \mathrm{KH}_{2} \mathrm{PO}_{4}, 11.5 \mathrm{~g} \mathrm{Na}_{2} \mathrm{HPO}_{4}$, adjust to $\mathrm{pH} 7.4$, and add water to $1 \mathrm{~L}$.

3. Thyroid hormones: 3,3',5-triiodo-L-thyronine $\left(\mathrm{T}_{3}\right)$ sodium salt and L-thyroxine $\left(\mathrm{T}_{4}\right)$ sodium salt. (Sigma, St . Louis, MO).

Concentrated stock solutions of these hormones can be prepared in advance and kept at $-20^{\circ} \mathrm{C}$ for at least $3 \mathrm{mo}: \mathrm{T}_{4}(1 \mathrm{mg} / \mathrm{mL})$ or $\mathrm{T}_{3}(4 \mathrm{mg} / \mathrm{mL})$ are dissolved in $50 \mathrm{~m} M \mathrm{NaOH}$, with vigorous vortex mixing, and aliquots are stored at $-20^{\circ} \mathrm{C}$ wrapped in aluminum foil. Working solutions are prepared before administration to the animals by diluting the stock solutions in PBS containing $0.1 \%(\mathrm{w} / \mathrm{v})$ bovine serum albumin (BSA) as follows:

a. $\mathrm{T}_{4}$ : add $20 \mu \mathrm{L}$ of stock solution to $980 \mu \mathrm{L}$ PBS-BSA (final concentration $2 \mu \mathrm{g}$ $\left.\mathrm{T}_{4} / 100 \mu \mathrm{L}\right)$.

b. $\mathrm{T}_{3}$ : add $250 \mu \mathrm{L}$ of stock solution to $750 \mu \mathrm{L}$ PBS-BSA (final concentration $1 \mu \mathrm{g} \mathrm{T} / \mu \mathrm{L})$.

4. Antithyroid drugs: $0.02 \%(\mathrm{w} / \mathrm{v})$ 1-methyl-2-mercapto-imidazore methimazole, MMI; Sigma, St. Louis, MO) and 1\% (WA potassium perchlorate.

5. Surgicalmaterial; scissors, forceps, hemostatie forceps, clamps, 20-25 gauge (G) needles with blunted tips. The size of the needle used depends on animal age.

6. Anesthetics: ketamine and medetomidine.

7. Fixative: $4 \%(\mathrm{w} / \mathrm{v})$ paraformaldehyde in $0.1 M \mathrm{~PB}, \mathrm{pH} 7.2-7.4$.

The fixative should be freshly prepared in the fume hood the day of perfusion. For $1 \mathrm{~L}$, heat $800\left[\mathrm{mit}\right.$ of water to $60-700^{\circ} \mathrm{C}$, dissolve $40 \mathrm{~g}$ of paraformaldehyde on a magnetic stirrer while heating and slowly add a few drops (6-8) of $1 \mathrm{MNaOH}$. When the solution clears add $100 \mathrm{~mL}$ of $1 M \mathrm{~PB}, \mathrm{pH} 7.2-7.4$, add water to $1 \mathrm{~L}$, filter, and use at room temperature (see Note 1).

8. $30 \%(\mathrm{w} / \mathrm{v})$ Sucrose solution. For $250 \mathrm{~mL}$ dissolve $75 \mathrm{~g}$ sucrose in fixative at room temperature.

9. Tissue-TeK OCT compound and cryostat knife size $16 \mathrm{~cm}$, type C.

10. Cryoprotective-buffered saline (CBS): $30 \%(\mathrm{v} / \mathrm{v})$ ethylenglycol, $30 \%(\mathrm{v} / \mathrm{v})$ glycerol, $40 \%$ (v/v) $0.1 M$ PB, pH 7.2.

\subsection{Materials for In Situ Hybridization}

Tubes, pipet tips, and glass material should be autoclaved. To prevent ribonuclease (RNase) contamination bake Pasteur and glass pipets for $2 \mathrm{~h}$ at $200^{\circ} \mathrm{C}$ and wear gloves at all times until the hybridization reaction has finished. Autoclaved high purity water is used in all steps. Diethyl pyrocarbonate (DEPC)-treated water is also used in some cases as indicated.

\section{Uncorrected Proof Copy}




\section{Uncorrected Proof Copy}

$\mathrm{Au}:$

Table

title

okay?

Table 1

\section{Preparation of Stock Solutions and Hybridization Buffer}

For a $45 \mathrm{~mL}$ stock solution, mix: $\quad$ Final concentration in hybridization buffer:

$25 \mathrm{~mL}$ Formamide (ultrapure)

$50 \%(\mathrm{v} / \mathrm{v})$

5 g Dextran sulfate

$10 \%(\mathrm{w} / \mathrm{v})$

$5 \mathrm{~mL}$ of $50 \mathrm{X}$ Denhardt's

$5 \mathrm{X}$

$6.25 \mathrm{~mL}$ of $5 \mathrm{M} \mathrm{NaCl}$

$0.62 M$

$1 \mathrm{~mL}$ of $1 M$ PIPES, pH 6.8

$20 \mathrm{~m} M$

$1 \mathrm{~mL}$ of $0.5 M$ EDTA

$10 \mathrm{~m} M$

$0.5 \mathrm{~mL}$ of $20 \%(\mathrm{w} / \mathrm{v})$

sodium dodecyl sulfate (SDS)

$0.2 \%(\mathrm{w} / \mathrm{v})$

Add water to $45 \mathrm{~mL}$. If SDS precipitates, warm the buffer to no more than $40^{\circ} \mathrm{C}$.

Divide in $1.8-\mathrm{mL}$ aliquots and keep frozen at $-20^{\circ} \mathrm{C}$.

This solution is valid for at least 3 mo.

Just before use, an aliquot is thawed Final concentration in

and the following is added:

hybridization buffer:

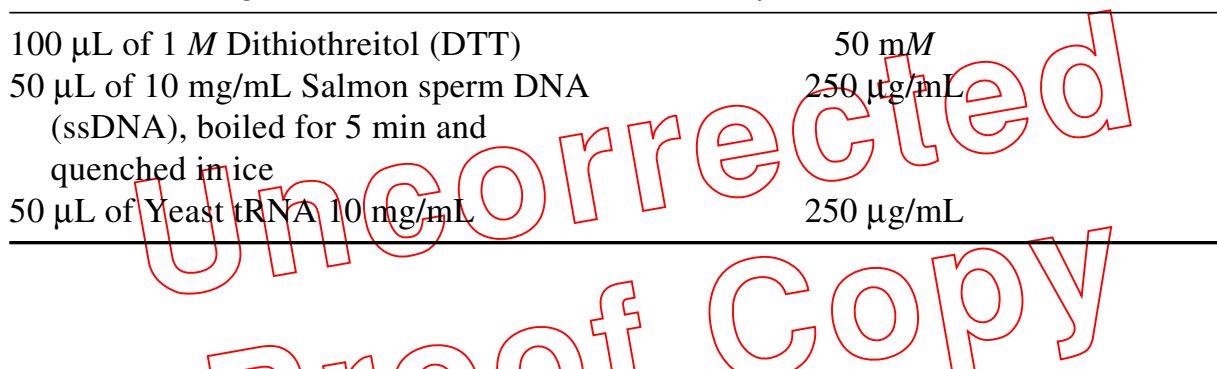

1. TE, $\mathrm{pH}$ 8.0: to prepare 500 mL, mix $5 \mathrm{~mL}$ of $1 M$ Tris- $\mathrm{HCl}, \mathrm{pH} 8.0$, and $1 \mathrm{~mL}$ $0.5 M$ EDTA in a total volume of $500 \mathrm{~mL}$ water, pass the solution through a $0.45-\mu \mathrm{m}$ fitter and autoclave.

2. DEPC-treated water: prepare a $0.1 \%(\mathrm{v} / \mathrm{v})$ solution of DEPC in a fume hood, tight close the bottle, shake the solution, heat at $37^{\circ} \mathrm{C}$ for $8 \mathrm{~h}$, and autoclave to inactivate the DEPC.

3. Washing vials, multiwell plates, slide racks, and staining troughs.

4. PBS-Triton X-100. Triton X-100 is used to permeabilize the tissue. For minimum tissue damage, the final Triton $\mathrm{X}-100$ concentration varies from 0.05 to $1 \%$ $(\mathrm{v} / \mathrm{v})$ depending on age: $0.05 \%$ for rat embryos and neonates, $0.1 \%$ for postnatal (P) d 5-15, 0.5\% from P16 to adults, and $1 \%$ for old animals.

5. Triethanolamine solution: $0.25 \%(\mathrm{v} / \mathrm{v})$ acetic anhydride in $0.1 \mathrm{M}$ triethanolamine, $\mathrm{pH}$ 8.0. Prepare the triethanolamine in water and filter through a $0.22-\mu \mathrm{m}$ filter. Take care because the acetic anhydride is very toxic and volatile, so it should be handled in a fume hood.

6. Hybridization buffer: prepare from stock solutions as indicated (Table 1) (see Note 2). For a 50-mL total working solution, a $45-\mathrm{mL}$ partial solution is prepared 


\section{Uncorrected Proof Copy}

Thyroid Hormone-Dependent Genes in The Brain

and kept frozen in 1.8-mL aliquots. Just before use, aliquots are thawed and the rest of components are freshly added.

7. Enzymes and other molecular biology reagents: restriction enzymes, RNA polymerases, RNase inhibitor, ribonucleotides, spin columns, proteinase K, DNA size markers, RNase A, and formamide, are of the highest analytical grade available.

8. $\left[{ }^{35} \mathrm{~S}\right] \mathrm{HTP}, 12.5 \mathrm{mCi} / \mathrm{mL}$, specific activity $1000-1500 \mathrm{Ci} / \mathrm{mmol}$.

9. Stringency wash solutions:

a. Solutions A, C, and D are prepared from a stock solution of 20X standard saline citrate (SSC) $(\mathrm{NaCl} 3 M$, sodium citrate $0.3 M, \mathrm{pH} 7.0)$ and $\beta$-Mercaptethanol is added just before use.

b. Solution A: 2X SSC, $10 \mathrm{~m} M \beta$-Mercaptethanol.

c. Solution B: $50 \mathrm{~m} M$ Tris-HCl, pH 7.5, $5 \mathrm{~m} M$ EDTA, $0.5 M \mathrm{NaCl}$, and $4 \mu \mathrm{g} / \mathrm{mL}$ RNase A.

d. Solution C: $0.5 \mathrm{X} \mathrm{SSC}, 50 \%(\mathrm{v} / \mathrm{v})$ formamide, $10 \mathrm{~m} M \beta$-Mercaptethanol. Formamide is added to diluted SSC.

e. Solution D: 0.1X SSC, $10 \mathrm{~m} M \beta$-Mercaptethanol.

10. Solution E: $0.05 \%$ Triton-X100 in $0.01 M$ PB, pH 7.2.

11. Superfrost ${ }^{\circledR}$ microscope slides.

12. Graded ethanol solutions $(50 \%, 70 \%, 90 \%)$ containing $0,3 M$ ammonium acetate when indicated.

13. Light-tight X-ray cassette and highresollution fitms.

14. Equipment needed for emulsion photography:

a. Dark room.

b. Tuvowater baths set at $43^{\circ} \mathrm{C}$.

c. Special lamp with an appropriate safe-light filter. The regular red light used in most dark rogms canno be bused. If no speciall lamp is ayaliable, perform all procedures in complete darkness. We use a sodium lamp, commercially available from different sources, which gives good illumination and is safe.

d. Anhydrous silica gel as desiccator.

e. Humidifier.

f. Thermometer.

g. Photographic emulsion: Kodak NTB2, Ilford K-5 or Amersham LM-1.

h. Dipping glass chambers, available from different providers: Amersham or Electron Microscopy Science.

i. Black, light-tight, microscope slide archive boxes.

j. Black electrical tape and plastic bags.

k. Metacrilate boxes for housing the emulsion and the emulsion-coated slides.

15. Photographic developer and fix solutions: developer D-19 (Kodak) and AGEFIX (AGFA).

16. Richardson's blue staining solution: prepare a stock solution containing $0.5 \%$ $(\mathrm{w} / \mathrm{v})$ Azure II, $0.5 \%(\mathrm{w} / \mathrm{v})$ methylene blue, and $0.5 \%(\mathrm{w} / \mathrm{v})$ sodium borate in water, and then filter through paper. Before use, this stock solution is diluted $1 / 20$ in $0.1 M \mathrm{~PB}, \mathrm{pH} 7.2$. 


\section{Uncorrected Proof Copy}

17. Blocking solution: $4 \%(\mathrm{w} / \mathrm{v})$ BSA, $0.1 \%(\mathrm{v} / \mathrm{v})$ Triton $\mathrm{X}-100,5 \%(\mathrm{v} / \mathrm{v})$ serum from the host of the secondary antibody, 0.1 M L-lysine in PBS, pH 7.2.

18. Antibodies: monoclonal or polyclonal primary antibodies specific for the proteins of interest and biotinylated secondary antibodies. Normal goat serum (NGS) and horse serum (HS).

19. Primary antibody solution: $4 \%$ (w/v) BSA, $0.1 \%$ (v/v) Triton X-100, $1 \%$ (v/v) serum in PBS, pH 7.2.

20. Secondary antibody solution: $4 \%$ (w/v) BSA, $0.1 \%(\mathrm{v} / \mathrm{v})$ Triton X-100, $5 \%$ (v/v) serum in PBS, pH 7.2.

21. Avidin-biotin-complex $(\mathrm{ABC})$ staining kit, available from different providers.

22. Diaminobenzidine (DAB) stock solution: $5 \mathrm{mg} / \mathrm{mL}$ in water, filter through $0.22-\mu \mathrm{m}$ filter, aliquot, and store at $-20^{\circ} \mathrm{C}$.

23. Developer DAB solution: $0.5 \mathrm{mg} / \mathrm{mL}$ DAB in PBS, $\mathrm{pH} 7.2$, plus $2.88 \mu \mathrm{L}$ of a $35 \% \mathrm{H}_{2} \mathrm{O}_{2} / 10 \mathrm{~mL}$ solution just before use (see Note 3).

\section{Methods}

\subsection{Handling of Animals}

\subsubsection{Generation of Hypothyroid Rats and Mice}

The induction of severe hypothyroidism is essential to observe changes in gene expression by thyroid hormene. Moderat hy pothyroidism leads to physiological changes aimed atmaintainning T3 concentrations in neural tissue within normal levels. The most inportant mechanism concerns deiodimase type 2 (D2). D2 is a selenoenzyme that catalyzes the remolat the iodine atom in the 5' position of T4 to generate the activer 9 rmone, T3. D2 activity is inbibited by T4 through a mechanism involving increased degradation of the enzyme in proteasomes. In situations of low T4, the increased expression and activity of D2, with the concomitant increased efficiency of T4 to T3 conversion, tends to maintain T3 concentrations constant (30). Therefore, only under very severe hypothyroid conditions are $\mathrm{T} 3$ concentrations low in the brain, in contrast with other tissues, such as the liver or kidney.

Hypothyroidism can be induced in the rat by surgical or chemical means. Surgical thyroidectomy procedures are difficult in mice, owing to the anatomical features of the mouse thyroid gland, which is not easy to remove. In mice, as in rats, chemical thyroidectomy, combining two different antithyroid drugs gives satisfactory results.

\subsubsection{SURGICAL THYROIDECTOMY}

1. Anesthetize the rat.

2. Open a longitudinal incision in the neck.

3. Separate the borders of the skin and the neck muscles until the thyroid gland is exposed.

\section{Uncorrected Proof Copy}




\section{Uncorrected Proof Copy}

Thyroid Hormone-Dependent Genes in The Brain

4. Pull off carefully each lobe of the gland.

5. Close the incision.

\subsubsection{Chemical Thyroidectomy}

A number of drugs interfere with hormone synthesis in the thyroid gland. The most commonly used are sodium or potassium perchlorate, 1-methyl, 2-mercaptoimidazole (MMI) and 6-n-propylthiouracil (PTU). Perchlorate blocks the active transport of iodide to the thyroid gland carried out via the Na-I symporter. MMI and PTU block the intrathyroidal oxidation of iodide and, therefore, the iodination of thyroglobulin. PTU, in addition, inhibits the activity of type 1 deiodinase (D1), so that less T3 is formed from T4 in the liver and kidney. Since D2 is not inhibited by PTU, it is possible that D1 inhibition by PTU would spare T4 as a substrate for D2 in the brain. In our laboratory, we prefer the use of MMI for this reason and, also, because it is readily soluble in water. PTU, in addition to being less soluble, requiring alkalinization with $\mathrm{NaOH}$, has a bitter taste and, therefore, is less tolerated by the animals. These drugs are given in the drinking water either alone or in combinations. In our laboratory, we use the following final concentrations: perchlorate: $10 \mathrm{~g}$ in $1 \mathrm{~L}$ of drinking water (1\%); MMI: $200 \mathrm{mg}$ ind of water $0.02 \%$

The most intense degree of postnatal hypothyyoidism is achieved by giving MMI to the pregnant dams and then performing thyroidectomy of the newborns. Taking int $\phi$ account the ontogenic dates for the T3 reeeptor (E14) and the thyroid gland (E18), and that hypothyroidism does not interfere with placental metabelism during the second half of pregnancy, we usuatly administer MMI contimuousty to the dams in the drinking water, starting around d 9 to 10 postconception. Newborns are then surgically thyroidectomized at P5. Since MMI crosses the placenta, the newborns develop goiter, which facilitates removal of the gland. With this protocol, a severe hypothyroidism is induced. The drawback is the high mortality, which is due not only to the surgical stress, but also to the fact that hypothyroidism is so profound that few pups survive after weaning. To ensure longer viabiliy, the pups need to be kept with their mothers. As an alternative to surgery, the combination of MMI and perchlorate works well also and results in lower mortality.

\subsubsection{Treatment with Thyroid Hormones}

The hormones are administered to the animals by intraperitoneal injection, according to different schedules, such as:

a. Acute $\mathrm{T} 3$ dose: $50 \mu \mathrm{g}$ of $\mathrm{T}_{3} / 100 \mathrm{~g}$ body weight $24 \mathrm{~h}$ before killing.

b. Replacement dose of T3: $0.3 \mu \mathrm{g} \mathrm{T}_{3}$ daily during at least $5 \mathrm{~d}$ before killing.

c. T4 treatment (replacement dose): $2 \mu \mathrm{g} / 100 \mathrm{~g}$ body weight.

\section{Uncorrected Proof Copy}

Au: loddide or iodine? 


\section{Uncorrected Proof Copy}

\subsection{Generating High Specific Activity RNA Probes}

The riboprobe is synthesized from a $200-400 \mathrm{bp}$ cDNA template from the gene of interest. Although longer probes may be used, this size range provides good diffusion into the tissue and good signal strength. Probes can be made from any region of the cDNA provided that there is no homology with related genes. The DNA template can be obtained by reverse-transcription polymerase chain reaction (RT-PCR) using specific primers, after which it is cloned in an appropriate vector containing promoters for phage RNA polymerases. Either sense or antisense RNA probes can be generated by linearizing the vector and using the appropriate polymerase. Use restriction enzymes leaving blunt or 5 '-protruding ends to avoid nonspecific initiation of the polymerases.

The probe can be labeled with any radioactive ribonucleotide, but UTP is preferred because it works better empirically than other labeled ribonucleotides. As isotopes, ${ }^{32} \mathrm{P},{ }^{33} \mathrm{P}$, or ${ }^{35} \mathrm{~S}$ may be used. ${ }^{35} \mathrm{~S}$ requires longer exposure times than ${ }^{32} \mathrm{P}$, but gives more resolution in the autoradiographs. ${ }^{33} \mathrm{P}$ on the other hand requires shorter exposure times than ${ }^{35} \mathrm{~S}$, while producing better resolution than ${ }^{32} \mathrm{P}$.

1. Prepare the transcription mix: add the following to $R \mathbb{N a s e}$-freemicrocentrifuge tube at room temperature: $1 \mathrm{\mu g}$ of Tinearized proteinase $\mathrm{K}$-treated DNA template; $2.5 \pi \mathrm{L}$ of 10 Xutransoriptien buffer provided with the polymerase (warm the buffer at room temperature tokepepsermidine into solution); $1 \mu \mathrm{L}$ each of $10 \mathrm{mM}$ ATP, CTP, and GTP; $1 \mu \mathrm{L} 0.75 \mathrm{M}$ DTT; $40 \mathrm{U}$ of RNase inhibitor; 5Q $\mu \mathrm{Ci}$ i 35 SJUTP, $12.5 \mathrm{mCi} / \mathrm{mL} ; 20 \mathrm{U}$ of appropriate RAA polymerase. usuallyt), T3, or SP6; DEPC water to a final Nolume of $25 \mu \mathrm{L}$.

2. Incubate 1 hat $37^{\circ} \mathrm{C}$.

3. Add $50 \mu \mathrm{L}$ TE, $\mathrm{pH} 8.0$, and extract with phenol-chloroform 1:1 (v/v).

4. Remove the unincorporated nucleotides by gel filtration chromatography over a RNase-free column.

5. Measure the vol and count a $1-\mu \mathrm{L}$ aliquot in scintillation fluid. Around $90 \mu \mathrm{L}$ of total volume is recovered with an average $5-6 \times 10^{5}$ counts per $\min (\mathrm{cpm}) / \mu \mathrm{L}$.

6. Add $1 \mu \mathrm{L}$ of $1 M$ DTT per $50 \mu \mathrm{L}$ of probe volume and store at $-70^{\circ} \mathrm{C}$ if not used immediately.

\subsection{Preparation of Brain Slices}

\subsubsection{Transcardiac Perfusion and Postfixation}

1. Anesthetize the animal by intraperitoneal injection of a mixture of an anesthetic (ketamine $4 \mu \mathrm{g} / 100 \mathrm{~g}$ body weight) and an analgesic (medetomidine 10-15 $\mu \mathrm{g}$ / $100 \mathrm{~g}$ body weight).

2. Place the animal on an operating table over a tray to collect the fixative while perfusing.

3. Cut open the thorax by a longitudinal incision and expose the heart.

\section{Uncorrected Proof Copy}




\section{Uncorrected Proof Copy}

Thyroid Hormone-Dependent Genes in The Brain

4. Open the catheter and let the fixative to drip slowly while introducing the blunted needle tip carefully through the left ventricle wall and into the beginning of the aorta. Air bubbles are avoided by letting the fixative to run slowly just before the needle is inserted into the heart.

5. Cut open the right atrium and perfuse at a rate of 90-140 drops/min, depending on animal age. Perfuse with at least $3 \mathrm{~mL}$ of fixative per gram of body weight.

6. Open the cranium and carefully remove the whole brain in a piece, taking care not to damage the surface of the organ. Immerse the brain in fixative and postfix overnight at $4^{\circ} \mathrm{C}$. Individual brains may be collected in 50-mL Falcon tubes containing the fixative.

\subsubsection{Cryopreserving the Tissue}

Immerse the brain in $30 \%$ sucrose solution and leave it undisturbed at $4{ }^{\circ} \mathrm{C}$ until the brain sinks. This usually takes 2 to $3 \mathrm{~d}$. At this point, the brain is ready to be frozen.

\subsubsection{Freezing and Cutting the Tissue}

1. Deposit a drop of OCT compound onto a piece of filter paper with the animal code written with pencil at the back.

2. Stick the cryoprotected brain to the paperin the de sired orientation, and place the whole piece over powderectry lice adding more on top of it until it is fully covered (see Note 4 )

3. Leave for 10 min and store the frozen tissue at $-70^{\circ} \mathrm{C}$ wrappedin transparent film.

4. To obtain the sections, allow the tissuelto equikibrate at $20^{\circ} \mathrm{C}$ inside the cryostat for 20-30 min before sectioning, to prepent distorsign and fracturing of the tissue.

5. Cut the tissue at -209C in 25-Mn-thick sections. The sections are collected in $2-\mathrm{mL}$ Eppendorf tubes (see Note 5) containing cold CBS and stored at $-70^{\circ} \mathrm{C}$. Sections are stable for years.

\subsection{In Situ Hybridization Using Radioactive Probes}

\subsubsection{Tissue Processing}

All incubations and washing steps should be performed under light shaking.

The washing vials are previously cleaned with detergent and rinsed with water. This is followed by rinsing with ethanol, soaking in $3 \% \mathrm{H}_{2} \mathrm{O}_{2}$ for 5-10 min at room temperature, and thoroughly rinsing with water.

1. Warm up the tube containing the frozen slices to room temperature, and place its content in a washing vial containing PBS. All procedures before prehybridization are performed at room temperature.

2. Rinse twice in PBS, for at least 5 min each.

3. Permeabilize the tissue by incubating the sections for 10 min in PBS containing Triton X-100. Triton concentration depends on animal age (see Subheading 3.2., item 4).

\section{Uncorrected Proof Copy}




\section{Uncorrected Proof Copy}

4. Rinse with PBS for at least $5 \mathrm{~min}$.

5. Deproteinize the tissue with $0.2 \mathrm{~N} \mathrm{HCl}$ for $10 \mathrm{~min}$.

6. Rinse with PBS for at least 5 min.

7. Acetylate sections with triethanolamine solution for $10 \mathrm{~min}$ to prevent nonspecific binding of the probe (see Subheading 2.).

8. Rinse with PBS for at least 5 min.

9. Postfix with $4 \%(\mathrm{w} / \mathrm{v})$ paraformaldehyde in PBS for $10 \mathrm{~min}$. This step is important in order to preserve the integrity of the tissue during hybridization reaction and stringency washes.

10. Rinse with PBS for at least $5 \mathrm{~min}$ and transfer the sections to 6-well plates.

\subsubsection{Prehybridization and Hybridization Steps}

These steps can be done in a water bath or in an oven.

1. Transfer the sections carefully, with the help of a bent Pasteur pipet, to a well of a 24-well plate containing $0.5 \mathrm{~mL}$ of hybridization buffer previously heated at $55^{\circ} \mathrm{C}$. Not more than 70 sections should be placed per well.

2. Incubate at $55^{\circ} \mathrm{C}$ for $3-5 \mathrm{~h}$.

3. Heat the labeled riboprobe $10 \mathrm{~min}$ at $68^{\circ} \mathrm{C}$ and quench in ice.

4. Add the denatured riboprobe to the sections in the hybridiation solution and incubate overnight at $55^{\circ} \mathrm{C}$. Final concentration of the probe should be above $10^{7} \mathrm{cpm} / \mathrm{mL}$. To avoridevaporation add PBS to the outer wells of the plate to make a humiditychamber, From this point on, it is not necessary to use RNase-free solutions and materiałs.

3.4.3. Stringency Washes and RNase Treatment

These steps help to rem the nonspecific binding of the probe.

All buffers should be preheated to the washing temperature.

1. First wash: transfer the sections from the 24-well plate to washing vials containing solution A and wash twice for $15 \mathrm{~min}$ at room temperature. The first wash is discarded as radioactive waste.

2. Second wash: $1 \mathrm{~h}$ at $37^{\circ} \mathrm{C}$ in solution B.

3. Third wash: twice for $1 \mathrm{~h}$ at $55^{\circ} \mathrm{C}$ in solution $\mathrm{C}$.

4. Fourth wash: $1 \mathrm{~h}$ at $68^{\circ} \mathrm{C}$ in solution D.

5. Finally rinse thoroughly with $\mathrm{PBS}$ and then with solution $\mathrm{E}$ at room temperature.

The washed hybridized sections can be either mounted directly on microscope slides as described below, or used for immunohistochemistry before mounting (see Subheading 4.5.).

\subsubsection{Mounting the Sections}

1. Place the sections in a Petri dish with solution $E$ and deposit them flat to the surface of superfrost microscope slides (see Note 6). 


\section{Uncorrected Proof Copy}

Thyroid Hormone-Dependent Genes in The Brain

2. Let the sections to air-dry for several hours.

3. Dehydrate the sections in graded ethanol solutions containing $0.3 \mathrm{M}$ ammonium acetate to prevent loss of hybridizing RNA (sequentially, 2 min each in 50\%, $70 \%, 90 \%$, ethanol, and then $10 \mathrm{~s}$ in 100\% ethanol).

4. Let the sections dry out under an air stream, for example in a fume hood, for $30 \mathrm{~min}$.

\subsubsection{Signal Detection}

Signal detection is accomplished by autoradiography, either by apposing an $\mathrm{X}$-ray film to the tissue sections for tissue level resolution, or by coating the sections directly with a photographic emulsion for cellular resolution. If the target mRNA is relatively abundant and does not need long exposure times, it is possible to perform both detection procedures in the same slide. If the probe needs long exposure times, it is better to perform both procedures in different slides. As a rule of thumb, it is not worth it to expose the sections for a longer time than the half-life of the isotope. Emulsion autoradiography needs around 3 to 5 times longer exposure than film autoradiography.

\subsubsection{Film Autoradiography}

1. The slides are apposed to sensitive fint for exampley Hyperfilm $\beta$-max ${ }^{\circledR}$ (Amersham, ,taking care that the sections contart the emulsion side of the film. The exposure fime yaries depending on the abundance of the target mRNA, and it may take from $3>0$ d.

2. Develop the $\beta$-max films manually Inder safe light. Ir is very important that all fluids are at $20^{\circ} \mathrm{C}$, especially the develloper. The film is immersed in D-19 developer, with the enulsion side upe for 4 min under light shaking.

3. Wash the fitm with running tap water and fixed 5-10 $\mathrm{min}$ in fix solution diluted 1:7. It is finally washed under running water at around $20^{\circ} \mathrm{C}$ for at least $5 \mathrm{~min}$.

4. The film is then air-dried.

The result of an experiment is illustrated in Fig. 1.

\subsubsection{Emulsion Autoradiography}

This is a relatively simple procedure, but great care should be paid to many factors that can affect the final results. Because the extreme sensitivity of the emulsion to light and radioactivity, it is necessary to avoid any source of radiation in the darkroom and during the storage of the emulsion and the coated slides. The procedure must be done in complete darkness or under a safe light (see Note 7). The room should have an adequate degree of humidity, which can be achieved by running a humidifier before the procedure, if needed.

1. Heat the emulsion in a water bath at $43^{\circ} \mathrm{C}$, for at least $15 \mathrm{~min}$. Place the dipping glass chamber in another bath at the same temperature and fill it with the warmed

\section{Uncorrected Proof Copy}




\section{Uncorrected Proof Copy}

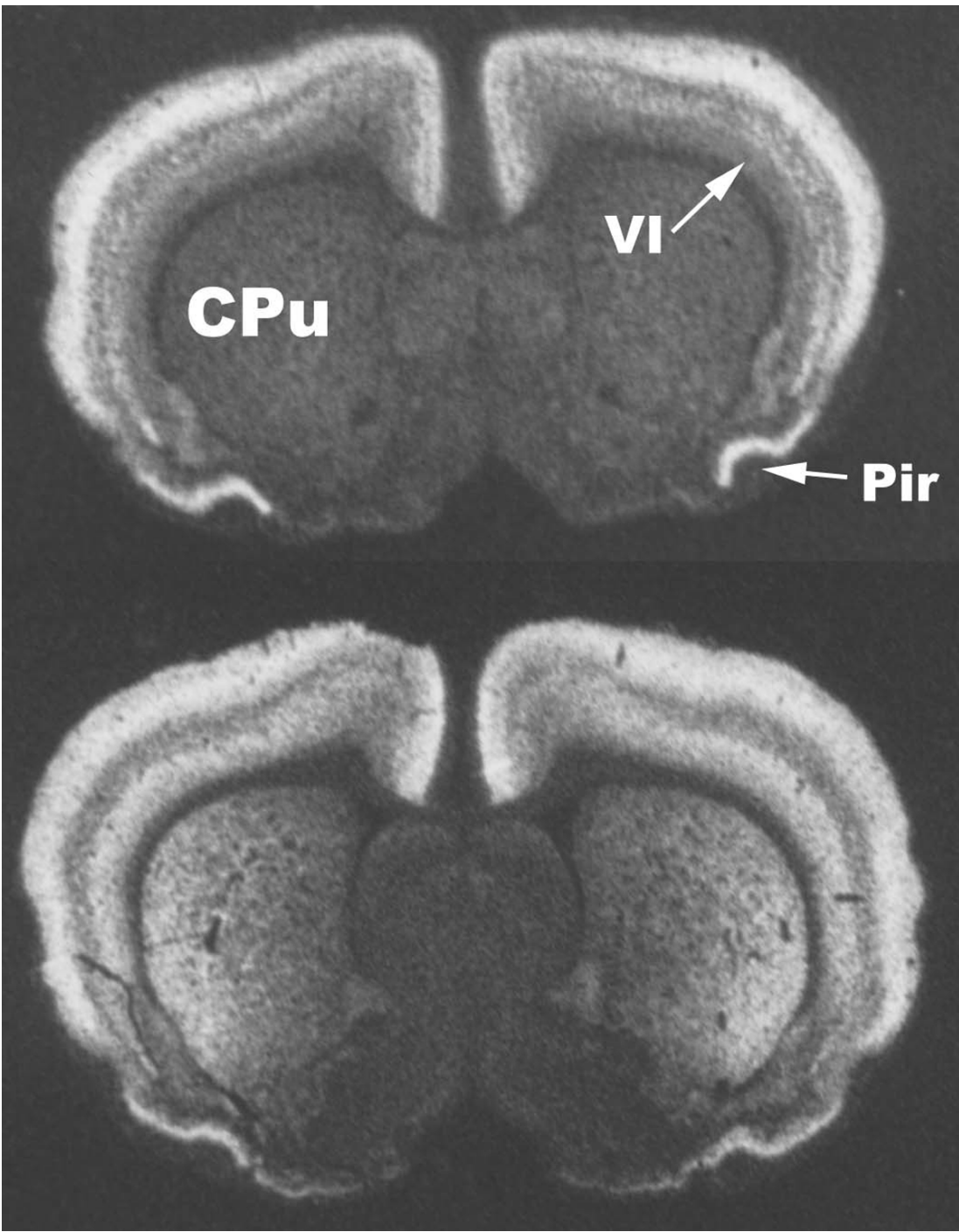

Fig. 1. Expression of RC3 in normal and hypothyroid rats. RC3 expression was studied by in situ hybridization using a $\left[{ }^{35} \mathrm{~S}\right] \mathrm{UTP}$-labeled riboprobe corresponding to the whole open reading frame. The results were examined by film autoradiography. To induce hypothyroidism, $0.02 \%$ MMI was giving in the drinking water to the pregnant dams, and the pups were thyroidectomized at P5. The hypothyroid and control rats were examined at P20. Upper panel: coronal section through the caudate of a hypothyroid rat. Lower panel: corresponding section of a normal control rat. Hypothyroidism induced a decreased RC3 expression in layer VI of the cortex and the caudate, and no changes in upper cortex layers or piriform cortex. Cpu, caudate-putamen; VI, layer VI of the cortex; Pir, piriform cortex. The data are from ref. 23. 


\section{Uncorrected Proof Copy}

Thyroid Hormone-Dependent Genes in The Brain

emulsion. The dipping glass chamber should have been cleaned with diluted $\mathrm{HCl}$, rinsed thoroughly with water, and dried.

2. Dip the slides, two at a time apposed by the backside, vertically into the emulsion for about $5 \mathrm{~s}$. It is important to dip the slides vertical into the emulsion without lateral movements to obtain a homogeneous emulsion thickness.

3. Take them out of the chamber and blot the tip of the slides with Kimwipe.

4. Place them as vertically as possible and let them to dry out for $1-1.5 \mathrm{~h}$.

5. Once dried, the slides are placed in a black slide box containing a small amount of desiccant wrapped in a Kimwipe. The position of the slides inside the box should be recorded. This helps in developing single slides to check the strength of the signal before processing the whole experiment.

6. The box is sealed and wraped in aluminum paper and placed in a metacrilate box at $4^{\circ} \mathrm{C}$. The exposure time is variable, as indicated above.

7. To develop the slides, the box is brought at room temperature before opening to prevent moisture: $1 \mathrm{~h}$ should be enough.

8. Prepare 3 ethanol-washed glass slide troughs containing, respectively; $250 \mathrm{~mL}$ of D-19 developer diluted 1:1 with distilled water; $250 \mathrm{~mL}$ distilled water; $250 \mathrm{~mL}$ of AGEFIX diluted 1:7 with distilled water.

Cool the solutions down to $16^{\circ} \mathrm{C}$. This can be accomplished by laxing the troughs on top of ice.

9. Under safe light, place the slides sequentidle with intermittent mixing up and down, 3 min in B-19 30s in water, 5-10 min in fix solution, and then wash for 30 min in running tap water at around $20^{\circ} \mathrm{C}$.

10. After the final wash in running tap water, stain for 2 min in Richardson's blue (see Subheading 3.2., item 16) andrimse briefly in water the excess dye. Other staining solutions may be ysed provided they are not acidic.

11. Differentiatefor approx 2 to 3 min in to\% ethanol, keeping control of the process to achieve the desired staining intensity.

12. Dehydrate in graded ethanol dilutions $(80 \%, 96 \%, 100 \%, 100 \%)$ for $3 \mathrm{~min}$ each (see Note 8), followed by $3 \mathrm{~min}$ in 100\% ethanol/xylene 1:1 (v/v), and then $5 \mathrm{~min}$ in xylene twice.

13. Coverslip the sections with DPX. The preparations are permanently stable if there are no air bubbles trapped between the coverslip and the tissue.

\subsection{Double In situ Hybridization and Immunohistochemistry}

\subsubsection{Tissue Processing}

After the washing steps from the hybridization reaction the floating sections in solution E, are ready for the immune reaction (see Subheading 4.4.3.).

\subsubsection{Immune Reaction and Signal Detection with the ABC Method}

Perform all the steps at room temperature under shaking except when indicated.

1. Incubate sections for $1 \mathrm{~h}$ in blocking solution (see Subheading 3.2., item 17).

2. Wash 5 min with $0.1 \%$ Triton $\mathrm{X}-100$ in PBS.

\section{Uncorrected Proof Copy}


3. Incubate sections with the primary antibody diluted in primary antibody solution (see Subheading 3.2., item 19, and Note 9).

4. Wash $3 \times$ with $0.1 \%$ Triton X-100 in PBS.

5. Incubate with the biotinylated secondary antibody diluted in secondary antibody solution (see Subheading 3.2., item 20). The secondary antibody recognizes the primary antibody Fc region (see Note 10).

6. Before incubation time is over, prepare the $\mathrm{ABC}$ solution following the kit directions. This solution can be prepared about $30 \mathrm{~min}$ before use.

7. Wash $6 \times, 5$ min each, with $0.1 \%$ Triton X-100 in PBS to completely remove the unbound secondary antibody.

8. Incubate the sections for $1 \mathrm{~h}$ in the $\mathrm{ABC}$ solution.

9. Wash twice for 5 ' with $0.1 \%$ Triton X-100 in PBS and then with PBS until foam disappears (it usually takes 4 washes of 5 min each).

10. Incubate the sections with developer DAB solution (see Subheading 3.2., item 23). The developing time is variable and needs to be monitored under the microscope in each experiment.

11. Stop the reaction with PBS and wash several times for $5 \mathrm{~min}$ (see Note 11).

12. Mount the sections on microscope slides as described in Subheading 4.4.4. Perform film and emulsion autoradiography as describedin Subheading 4.4.5.

\section{A result of such an experiment is seen.jin Fig. 2}

\subsection{Analysis of Results}

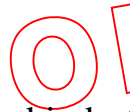

All results may be analyzed in both qualitative and quantitative wayys.

\subsubsection{Autoradiograms}
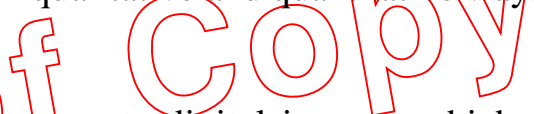

The X-ray films are scanned to generate digital images, which can be quantified with appropriate programs, such as National Institutes of Health (NIH) Image.

\subsubsection{Microscopy Slides}

Optical observation with light and dark field with a standard light microscope.

\section{Notes}

1. Paraformaldehyde is toxic, so the fixative should be prepared in a fume hood. It is very important to prepare correctly the fixative to obtain the best preservation of the tissue. Do not overheat the solution more than $60^{\circ} \mathrm{C}$.

2. Use the sodium salt of PIPES, which is easier to dissolve than the free acid. 50X Denhardt's is 1\% (w/v) BSA, 1\% (v/v) Ficoll 400 and 1\% (w/v) polyvinylpyrrolidone. $20 \%$ SDS is prepared in water and autoclaved. The NaCl, PIPES, EDTA, and Denhardt's solutions must be filtered through a $0.22-\mu \mathrm{m}$ filter before adding to the hybridization buffer.

Dissolve the yeast tRNA in DEPC water. The ssDNA is dissolved in water by stirring in a beaker. It takes time to dissolve. Aliquots of both solutions are kept at $-20^{\circ} \mathrm{C}$.

\section{Uncorrected Proof Copy}




\section{Uncorrected Proof Copy}

Thyroid Hormone-Dependent Genes in The Brain

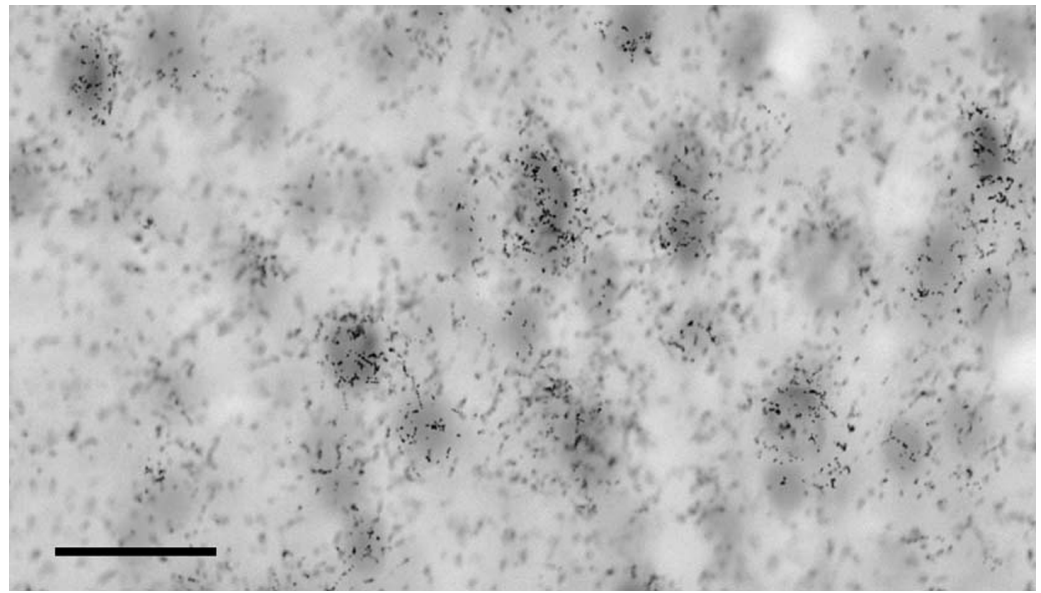

Fig. 2. Emulsion autoradiography using a labeled RC3 riboprobe combined with immunohistochemistry for $\mathrm{T} 3$ receptor $\beta 2$ isoform in the rat retrosplenial cortex. Photography was carried out using a $63 \mathrm{X}$ immersion objective. Note the black silver grains over receptor positive cells. The scale bar equals $25 \mu \mathrm{m}$. Data are from ref. 31 .

3. Take extra care becanse $D A B$ is a carcinfogn.ADI residues should be inactivated with bleach prior to disearding. It is also very hygroscopic, so the bottle should be warmed at roon temperature before opening to avoid moisture.

4. The brain or brain blocks should be placed on the filer paper in such a/way that the cutting plane is parallel to the paper base. For coronal sections, we routinely separate the cere bram and the cenebellum by cutting perpendicularly at the level of the collicuti, and stick each part to the paper by the cutting plane. Brain blocks can be sinillarly prepared by cutting through different planes as desired.

5. For coronal sections, a whole adult rat brain can be collected into 3 series of 5 tubes each. The first set of tubes, labeled A1-A5 contains alternating serial sections from the olfactory bulb to the fimbria of the hippocampus. The second set, labeled B1-B5 contains the sections from the rest of the cerebrum. The third set, tubes C1-C5 contains the cerebellar sections. Thus, if one tube of each set is used, a whole representation of the brain is present in a single experiment. Each tube contains enough sections to be hybridized with 3 probes. In this way, one adult rat brain can be hybridized with 15 different probes.

6. If the slides are to be used for emulsion photography, the sections should be mounted in the lower $2 / 3$ of the slide to ensure a uniform emulsion thickness.

7. Check that there is absolutely no light sources other than the safe light in the room where the dipping is being perform. Take care to cover all possible sources of light from the water baths with black tape, and avoid static electricity sparks. Advertise very clearly with signs outside the room that there is an experiment running to avoid anybody to go in.

8. The ethanol solutions used in these steps should not contain ammonium acetate because otherwise the stain gets out of the sections.

\section{Uncorrected Proof Copy}


9. The temperature and the time of incubation depends on the specific antibody used and also on antibody dilution. We generally incubate overnight at $4{ }^{\circ} \mathrm{C}$, but in many cases, this has to be empirically determined.

10. Dilution of secondary antibody, incubation time, and temperature are specified in the $\mathrm{ABC}$ staining kit instructions, but sometimes has to be optimized empirically.

11. It is important to stop the reaction when the brown color resulting from DAB oxidation is still light, so that the hybridization grains after emulsion photography can still be seen over the immune background color.

\section{Acknowledgments}

We acknowledge the help provided by Dr. Luis de Lecea (Scripps research Institute, La Jolla, CA) in setting up the in situ hybridization and immunohistochemistry techniques described in this chapter. Work in our laboratory is supported by Grant No. PM98-0018 from DGICYT. A.G.-F. is supported by an investigator contract from the C.S.I.C., Spain.

\section{References}

1. Porterfield, S. P. and Hendrich, C. E. (1993) The role $\Phi$ fthyroid hormones in prenatal and neonatal neurological development current perspectives Endocr. Rev. 14, 94-106.

2. Legrand, J. (1984) Effects of thyroid hormones on central nervous system, in Neurobehavioral Teratology (Yanai, J., ed.), Elsevier Science Publishers, Amsterdam, pp. 331-363.

3. Pérez-Castillo, A., Bernal, J., Ferreire, \$8., and Pans, T.(1985) The early ontogenesis of thyroidhormone receptorin the rat fetus. Endockinology 117, 2457-2461.

4. Bradley, D.J., Towle, H. G., and Young, W. S. (1992) Spatial and temporal expression of $\alpha$ - and $\beta$-thyroid hormone receptor mRNAs, including the $\beta 2$-subtype, in the developing mammalian nervous system. J. Neurosci. 12, 2288-2302.

5. Bernal, J. and Pekonen, F. (1984) Ontogenesis of the nuclear 3,5,3'-triiodothyronine receptor in the human fetal brain. Endocrinology 114, 677-679.

6. Bernal, J. and Guadaño-Ferraz, A. (1998) Thyroid hormone and the development of the brain. Curr. Op. Endocrinol. Diabetes 5, 296-302.

7. Rogister, B., Ben-Hur, T., and Dubois-Dalcq, M. (1999) From neural stem cells to myelinating oligodendrocytes. Mol. Cell. Neurosci. 14, 287-300.

8. Sutcliffe, J. G. (1988) The genes for myelin revisited. Trends Genet. 4, 211-213.

9. Vega-Núñez, E., Menéndez-Hurtado, A., Garesse, R., Santos, A., and PerezCastillo, A. (1995) Thyroid hormone-regulated brain mitochondrial genes revealed by differential cDNA cloning. J. Clin. Invest. 96, 893-899.

10. Alvarez-Dolado, M., Gonzalez-Moreno, M., Valencia, A., Zenke, M., Bernal, J., and Muñoz, A. (1999a) Identification of a mammalian homologue of the fungal Tom70 mitochondrial precursor protein import receptor as a thyroid hormoneregulated gene in specific brain regions. J. Neurochem. 73, 2240-2249.

11. Iglesias, T., Caubín, J., Zaballos, A., Bernal, J., and Muñoz, A. (1995) Identification of the mitochondrial NADH dehydrogenase subunit 3 (ND3) as a thyroid

\section{Uncorrected Proof Copy}


hormone regulated gene by whole genome PCR analysis. Biochem. Biophys. Res. Comm. 210, 995-1000.

12. Alvarez-Dolado, M., Iglesias, T., Rodríguez-Peña, A., Bernal, J., and Muñoz, A. (1994) Expression of neurotrophins and the trk family of neurotrophin receptors in normal and hypothyroid rat brain. Mol. Brain Res. 27, 249-257.

13. Neveu, I. and Arenas, E. (1996) Neurotrophins promote the survival and development of neurons in the cerebellum of hypothyroid rats. J. Cell Biol. 133, 631-646.

14. Aniello, F., Couchie, D., Gripois, D., and Nunez, J. (1991) Regulation of five tubulin isotypes by thyroid hormone during brain development. J. Neurochem. 57, 1781-1786.

15. Aniello, F., Couchie, D., Bridoux, A. M., Gripois, D., and Nunez, J. (1991) Splicing of juvenile and adult tau mRNA variants is regulated by thyroid hormone. Proc. Natl. Acad. Sci. USA 88, 4035-4039.

16. Ghorbel, M. T., Seugnet, I., Hadj-Sahraoui, N., Topilko, P., Levi, G., and Demeneix, B. (1999) Thyroid hormone effects on Krox-24 transcription in the post-natal mouse brain are developmentally regulated but are not correlated with mitosis. Oncogene 18, 917-924.

17. Koibuchi, N. and Chin, W. W. (1998) ROR $\alpha$ gene expression in the perinatal rat cerebellum: ontogeny and thyroid hormone regulation. Endecrinotogy 139, 2335-2341.

18. Denver, R. J., Ouellet, L., Furling,D., Kobatashi, A.,Fuji-Kuriyama, Y., and Puymirat, J. (1999) Basic transcription element-binding protein (BTEB) is a thyroid hormone-regulated gene in the developing central nervous-system. Evidence for a role in neurite outgrowth. J. Biol Chem. 274, 23, 128-23,134.

19. Cuadrado, A., Bernal, J., and Muñoz A. (1999) Identification bf the mammalian homolog of the splicing regutator Suppressor-of-white-apricot as a thyroid hormone regulated gene. Mgl. Brain. Res. 71, 332-340.

20. Alvarez-Do ado, M, Gonzalez-Sancho, J. M., Bernal, J., and Muñoz, A. (1998) Developmental expression of tenascin-C is altered by hypothyroidism in the rat brain. Neuroscience 84, 309-322.

21. Alvarez-Dolado, M., Ruiz, M., del Rio, J. A., et al. (1999b) Thyroid hormone regulates reelin and dab1 expression during brain development. J. Neurosci. 19, 6979-6973.

22. Alvarez-Dolado, M., Cuadrado, A., Navarro-Yubero, C., et al. (2000) Regulation of the L1 cell adhesion molecule by thyroid hormone in the developing brain. Mol. Cell. Neurobiol. 16, 499-514.

23. Iñiguez, M. A., De Lecea, L., Guadaño-Ferraz, A., et al. (1996) Cell-specific effects of thyroid hormone on RC3/neurogranin expression in rat brain. Endocrinology 137, 1032-1041.

24. Krebs, J. and Honegger, P. (1996) Calmodulin kinase IV: expression and function during rat brain development. Biochim. Biophys. Acta 1313, 217-222.

25. García-Fernández, L. F., Urade, Y., Hayaishi, O., Bernal, J., and Muñoz, A. (1998) Identification of a thyroid hormone response element in the promoter region of the rat lipocalin-type prostaglandin D synthase (beta-trace) gene. Mol. Brain Res. 55, 321-330.

\section{Uncorrected Proof Copy}




\section{Uncorrected Proof Copy}

26. Falk, J. D., Vargiu, P., Foye, P. E., et al. (1999) Rhes: a striatal-specific Ras homolog related to Dexras1. J. Neurosci. Res. 57, 782-788.

27. Valentino, K. L., Eberwine, J. H., and Barchas, J. D. (1987) In Situ Hybridization: Applications to Neurobiology, Oxford University Press, New York.

28. Wisden, W. and Morris, B. J. (1994) In Situ Hybridization Protocols for the Brain, Academic Press, London.

29. Polak, J. M. and McGee, J. O. D. (1998) In Situ Hybridization: Principles and Practice, Oxford University Press, Oxford.

30. Obregón, M. J., Ruiz de Oña, C., Calvo, R., Escobar del Rey, F., and Morreale de Escobar, G. (1991) Outer ring iodothyronine deiodinases and thyroid hormone economy: responses to iodine deficiency in the rat fetus and neonate. Endocrinology 129, 2663-2673.

31. Guadaño-Ferraz, A., Escámez, M. J., Morte, B., Vargiu, P., and Bernal, J. (1997) Transcriptional induction of RC3/neurogranin by thyroid hormone: differential neuronal sensitivity is not correlated with thyroid hormone receptor distribution in the brain. Mol. Brain Res. 49, 37-44.

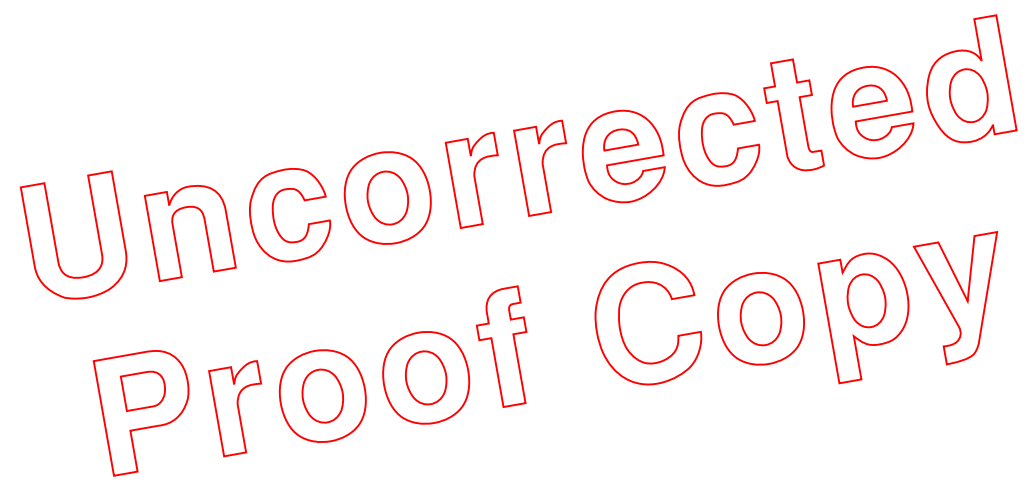

